\title{
Should American Antitrust Laws Protect Only American Consumers?
}

\section{Thanh Phan}

Ph.D. Candidate, Law Faculty, University of Victoria, USA

*E-mail for correspondence: thanhpc@uvic.ca

Received: May 13, 2017;

Accepted: July 29, 2017;

Published: Sep 16, 2017

Source of Support: Nil

No Conflict of Interest: Declared

\begin{abstract}
The United States adopted its first antitrust statute in 1890. Despite their long history of development, American antitrust laws do not specify any objectives. The primary objective of the American antitrust laws centers a long-standing debate among many scholars. This paper firstly argues that the American antitrust laws were designed to promote consumer welfare. However, exemptions for export cartels confine the concept of "consumers" protected by the Sherman Act to those in the U.S territory. This paper secondly proposes that exemptions for export cartels should be abolished for two reasons. First, the exemptions make American antitrust policy inconsistent because they do not reflect the objective that promotes consumer welfare. Second, from an international perspective, exemptions for export cartels are inconsistent with the efforts of the American Government to apply the Sherman Act extraterritorially —a measure that aims to protect consumers from international cartels.
\end{abstract}

Keywords: Competition law, export cartel, consumer welfare, economic efficiency, unfettered competition, Sherman Act, Webb-Pomerene Act

\section{INTRODUCTION}

The United States adopted its first antitrust statute in 1890. Despite their long history of development, American antitrust laws do not specify any objectives. The primary objective of the American antitrust laws centers a longstanding debate among many scholars. Previous discussions, however, do not articulate the objectives of the Sherman Act with the consistency of the American antitrust policy. This paper firstly, by analyzing the legislative history, documents made by the American competition authorities, and the decisions of the U.S. Supreme Court, argues that the American antitrust laws were designed to promote consumer welfare. However, exemptions for export cartels confine the concept of "consumers" protected by the Sherman Act to those in the U.S territory. This paper secondly proposes that exemptions for export cartels should be abolished for two reasons that make the American antitrust policy inconsistent. First, the exemptions do not reflect the objective that promotes consumer welfare. In the context of globalization, the concept of "society" is no longer confined to any local territory but refers to the "global society" (Zumbansen, 2012, p. 309). Antitrust laws, therefore, should refer "consumers" to "global consumers" but not those in any specific national territory. Second, from an international perspective, exemptions for export cartels are inconsistent with the efforts of the American
Government to apply the Sherman Act extraterritorially-a measure that aims to protect consumers from international cartels (Phan, 2016, pp. 450-464).

This paper consists of two sections. The first section discusses the economic objectives of competition law and argues that promoting consumer welfare is the primary objective of American antitrust laws. The second section analyses exemptions for export cartels and proposes that these measures should be abolished because they make American antitrust policy inconsistent.

\section{Main Objective of the American Antitrust Laws}

The U.S. Congress passed the Sherman Act in 1890. In 1914, Congress enacted the Federal Trade Commission Act, and the Clayton Act. These statues are the principal antitrust laws of the U.S. (Federal Trade Commission).

The U.S. competition laws are known as "antitrust" because they were designed as measures against illegal combinations in form of trusts (Orbach, 2013, p. 2254). Per Senator Sherman, the Bill stemmed from the fact that "associated enterprise and capital [had] invented a new form of combination commonly called trusts, that [sought] to avoid competition by combining the controlling corporations ... and placing the power and property of the combination under the government of a few individuals" 
('Senate Debate', 1890, p. 2457). Regulating trusts means preventing restraints of trade, securing competition which results in "low prices, better conditions of supply, and prosperity opportunities"(Orbach, 2013, p. 2262).

The Sherman Act, however, does not provide any clear objectives for the U.S. competition law. The Bill that introduced the Sherman Act in the Senate in the first session of the $51^{\text {st }}$ Congress said:

that all arrangements, contracts, agreements, trusts, or combinations between persons or corporations made with a view, or which tend, to prevent full and free competition ...., and all arrangements, contracts, agreements, trusts, or combinations between persons or corporations designed, or which tend, to advance the cost to the consumer of any such articles, are hereby declared to be against public policy, unlawful, and void (Senate Bills, 1889, p. 69).

The phrases "to prevent full and free competition" and "to advance the cost to the consumer" suggest that promoting competition and protecting consumer welfare are two objectives of the bill put before Senate. The Senate redrafted the Bill four months later replacing these key words by the phrase "in restraint of trade or commerce," which is used in the Sherman Act now (The Senate Committee on the Judiciary, 1890). The Senate Committee on the Judiciary, however, did not provide a report to explain the redrafted version of the Bill.(Ibid.) Likewise, neither the Clayton Act nor the Federal Trade Commission Act articulate objectives. The legislative history of the Sherman Act shows that the words "to prevent full and free competition" and "to advance the cost to the consumer" were expressly rejected, and that none of the principal U.S. antitrust laws articulate an objective. Thus, the courts have emphasized different goals and scholars have debated whether the objective of the Sherman Act is to promote free competition, economic efficiency that increases total welfare, or consumer welfare (Hovenkamp, 2011, sec. 2.1-2.2).

\section{Promoting "Unfettered" Competition}

Some courts, scholars and practitioners recognize that protecting competition is the objective of the American antitrust laws. By the end of the $19^{\text {th }}$ century, law makers perceived that protecting small businesses from trusts was a means to protect the economy from harmful trusts.(Orbach, 2013, p. 2267) This suggests promoting competition was initially regarded as a means of protecting the economy.

Over time, their understanding of the meaning of "protecting competition" seems to have changed to fit their understanding of its ultimate goals (Ibid., p. 2268). Some scholars discuss this objective as the protection of consumer's choice. They assert that illegal business practices are those that distort "the supply of options by imposing restrictions on the variety of prices and products that the free market would offer"'(Lande and Averitt, 1998, p. 47; Wright and Ginsburg, 2012a, p. 2409). For example, a price fixing agreement deprives consumers of the right to choose better prices or an illegal merger restricts consumers choice in terms of product variety, quality and price (Lande and Averitt, 1998, p. 47). In addition, a market with fewer firms is deemed to produce dynamic inefficiencies, which also result in fewer choices for consumers due to the lack of innovation (Wright and Ginsburg, 2012b, p. 2413). By protecting the co-existence of many firms in a market, competition law makes the market competitive and thus provides consumers with a wide range of options (Lande and Averitt, p. 44).

Early on, courts and scholars thought that competition was a process that would have many benefits, including keeping people employed in small businesses, preventing the growth of monopolies that hurt consumers with high prices and low quality, and preventing large enterprises and their owners from dominating politicians (Orbach, 2013, p. 2267). To achieve these outcomes, they thought that protecting competition meant keeping the number of rivals high and their size small (370 US 294, 1962, p. 344).

The belief that keeping the number of rivals high and their size small and unfettered by restraints is what "protecting competition" meant in the historical context in which the Sherman Act was debated in the U.S in 1890. The legislators were concerned about restraints of trade or commerce, small firm competitiveness, and excessive market power (Orbach, 2013 , p. 2262). Antitrust laws were written to protect "small dealers and worthy men" (166 US 290, 1897, p. 323). The Supreme Court shared the belief that "protecting competition" not only kept prices down and quality up, but also preserved democratic values. Justice Black wrote in Northern Pacific Railway Co. v. U.S. in 1958 that "the Sherman Act was designed to be a comprehensive charter of economic liberty aimed at preserving free and unfettered competition as the rule of trade... But even were that premise open to question, the policy unequivocally laid down by the Act is competition" (356 US 1, 1958, p. 4) [Emphasis added].

Justice Warren also observed in Brown Shoe Co, Inc $v$ United States that, it is competition, not competitors, which the Act protects... We cannot fail to recognize Congress' desire to promote competition through the protection of viable, small, locally owned business. Congress appreciated that occasional higher costs and prices might result from the maintenance of fragmented industries and markets... We must give effect to that decision (370 US 294, 1962, p. 344).

This means protecting competition aims to protect the number of competitors in markets or to remove barriers to the number increasing-a process that may result in inefficiencies due to the lack of economies of scale.

Economists, even at that time, were afraid that "the law would impede attainment of superior efficiency promised by new forms of industrial organization" (Kovacic and Shapiro, 2000, p. 44). However, the U.S Supreme Court in U.S. $v$ Topco Assoc. continued to interpret restraints by small buyers' intra-brand competition that would enhance 
inter-brand competition to be illegal because the restraints were contrary to the unfettered competition goal of the Sherman Act. The Court said:

antitrust laws in general, and the Sherman Act in particular, are the Magna Carta of free enterprise. They are as important to the preservation of economic freedom and our free-enterprise system as the Bill of Rights is to the protection of our fundamental personal freedom. And the freedom guaranteed each and every business, no matter how small, is the freedom to compete ... If a decision is to be made to sacrifice competition in one portion of the economy for greater competition in another portion, this . . . is a decision that must be made by Congress and not by private forces or by the courts (405 US 596, 1972, pp. 610-611).

It was not until the late 1970s, when scholars and courts started to rely more heavily on economics, that they understood competition as a process that promotes efficiency or consumer welfare.

Earlier court decisions thought that protecting competition meant protecting rivalry among many producers, even small inefficient ones. For the past forty years, however, the courts and scholars have said that protecting competition means protecting only the types of rivalry that promote efficiency or consumer welfare. Some scholars also assert that maintaining a large number of competitors in a market "would inevitably reduce consumer and total welfare by shifting the focus of antitrust analysis from efficiency to more easily observed but misleading proxies for consumer welfare, to wit, the number of firms on offer in a market" (Wright and Ginsburg, 2012, p. 2422). These scholars argue for the second objective of competition law as discuss in subsection 1.2.

\section{Promoting Efficiency}

Some scholars believe that enhancing economic efficiency should be the direct goal of the American antitrust laws because this objective helps to enhance the overall economic welfare of society which ultimately benefits consumers including consumers in the relevant market and consumers in other markets. Promoting efficiency as a primary goal of competition law is also supported by the Chicago School of antitrust, which asserts that "a policy that produces greater gains to business than losses to consumers is considered to be efficient" (Cseres, 2007, p. 125). Scholars supporting the objective of promoting efficiency argue that promoting consumer welfare should not be a direct objective of competition law because the consumer welfare standard merely considers how economic welfare should be allocated between different social groups without considering how much economic welfare of society is produced (Ibid., p. 127). The authors also doubt the promotion of competition as a direct objective of competition law because a competitive market consisting of a large number of small firms may provide consumers with more choices and make price closer to cost but it also result in high cost due to the lack of productive efficiency (Hovenkamp, 2012, p. 2471).

The authors assert that promoting economic efficiency is the main objective of American antitrust laws for the following four reasons. First, the Sherman Act is an extension of the common law, which pursues economic efficiency (Kleit, 1992, p. 30). Second, no "consumerist" group was available to lobby the Congress when it passed the Act in 1890 (Ibid.) Third, the Sherman Act is enforced by the judiciary, not administrative agencies that may be influenced by interests groups (Ibid.) Fourth, taking efficiency as the objective of the antitrust laws may result in higher product quality with lower price and better competitiveness for American firms in international markets (Kovacic and Neilson, 1997, p. 4).

The U.S. Supreme Court also discussed in Connell Const Co, Inc $v$ Plumbers and Steamfitters Local Union No 100 that "competition based on efficiency is a positive value that the antitrust laws strive to protect" (421 US 616, 1975, p. 623). The Court, however, did not provide further explanation for this objective of the antitrust laws. There are only three cases citing this opinion and the latest case was in 1989.

\section{Promoting Consumer Welfare as the Primary Objective of the U.S. Antitrust Laws}

Many scholars argue that the primary objective of the U.S. antitrust laws is the promotion of consumer welfare. Consumer welfare is "the maximization of consumer surplus, which is the part of total surplus given to consumers" (Cseres, 2007, p. 124). Viewing antitrust as a means to protect "a state of competition, freedom from restraints of trade, low prices, better conditions of supply, and prosperity opportunities" is consistent with the objective of promoting consumer welfare because it ultimately provides consumers with low prices and better conditions of supply (Orbach, 2013, p. 2262). Robert H. Lande contends that the Congress passed the antitrust laws to achieve economic objectives, but the main concern was about consumers' wealth deprived by firms with market power (Lande, 1982, p. 68). Similarly, Carl Shapiro considers the promotion of consumer welfare to be the ultimate objective of the American antitrust laws. He wrote that " $[t]$ he goal of antitrust is to ensure that firms compete to serve the needs of consumers, as reflected by their market demand for goods and services, even when vigorous competition is contrary to the interests of powerful and entrenched suppliers" (Shapiro, 2009). He asserts that the enforcement of competition law serves to drive the market to consumer preferences (Ibid.).

There are four reasons why the promotion of consumer welfare is the primary objective of the U.S. antitrust laws. First, the Senate debate suggests that in 1890 the Senate aimed to protect consumer when they drafted the Sherman Act. Per Senator George,

the right of action against the persons in the combination is given to the party damnified. Who 
is this party injured, when, as prescribed in the bill, there has been an advance in the price by the combination? The answer is found in the bill itself in the words, 'intended to advance the cost to the consumer of any such articles.' The consumer is the party 'damnified or injured' ('Senate Debate', 1890, pp. 1767-1768) [Emphasis added].

Senator Sherman's explanation also indicates that the Act was designed to protect consumer's interests from selfish behavior of illegal combinations. He said

the bill, as I would have it, has for its single object to invoke the aid of the courts of the United States to deal with the combinations described in the first section ... [An illegal combination] can control the market, raise or lower prices, as will best promote its selfish interests ... The law of selfishness, uncontrolled by competition, compels it to disregard the interest of the consumer.... It is this kind of combination we have to deal with now ('Senate Debate', 1890, p. 2457) [Emphasis added].

The House Judiciary Committee had the same opinion about the objective of the Sherman Act. They announced that the law would not interfere with efficiencies or harm consumers, but would protect consumers from monopoly (Bork, 1978).

The second reason is that horizontal cartels are per se violations of the Sherman Act. Robert H. Bork wrote that "a per se rule against cartels is inconsistent with values other than consumer welfare because it permits no other value to interfere with competitive pricing" (Bork, 1978, p. 62).

Third, the U.S. government also considers the promotion of consumer welfare as the main objective of the Sherman Act. In an amicus curiae brief supporting the petitioner in Reiter $v$. Sonotone Corp, the U.S. government wrote that " $\mathrm{t}]$ he primary purpose of the Sherman Act was consumer protection" ('Brief for the U.S. as Amicus Curiae in 442 U.S. 330 (1979)', 1979, p. 12). Promoting consumer welfare as the primary objective of the U.S. antitrust laws can be found in the Horizontal Merger Guidelines issued by the U.S. Department of Justice and the FTC (the Guidelines). The Agencies also credit efficiencies besides assessing adverse competitive effects of a merger. The Agencies "will not challenge a merger if cognizable efficiencies are of a character and magnitude such that the merger is not likely to be anti-competitive in any relevant market."(U.S Department of Justice and Federal Trade Commission, 2010, p. 30). The Agencies, however, prioritize the promotion of consumer welfare in their merger review. They write that:

[t]he greater the potential adverse competitive effect of a merger, the greater must be the cognizable efficiencies, and the more they must be passed through to customers, for the Agencies to conclude that the merger will not have an anticompetitive effect in the relevant market ... In adhering to this approach, the Agencies are mindful that the antitrust laws give competition, not internal operational efficiency, primacy in protecting customers (Ibid., p. 31) [Emphasis added].
The fourth and the most important reason why promoting consumer welfare is the main objective of the Sherman Act is the opinion of U.S. Supreme Court (Hovenkamp, 2012, p. 2476). In Reiter $v$ Sonotone Corp in 1979, Justice Rehnquist cited Bork's opinion that "Congress designed the Sherman Act as a 'consumer welfare prescription" (442 US 330, 1979, p. 343). He held that "the essence of the antitrust laws is to ensure fair price competition in an open market."(Ibid., p. 342) This means the ultimate objective of the antitrust laws is to benefit consumers by fair price. This opinion was cited by nineteen cases including Gelboim v. Bank of America Corp decided on May 23, 2016 (823 F3d 759 (2nd Cir)., 2016).

Similarly, Justice White wrote in Spectrum Sports, Inc $v$ McQuillan: "[t]he purpose of the Act is not to protect businesses from the working of the market; it is to protect the public from the failure of the market" (113 US 884, 1993, pp. 891-892). Although the Court did not provide further explanation, the most vulnerable victim of the market failure must be consumer. Thirty-two cases cited this opinion and the most recent case was Merced Irrigation District $v$. Barclays Bank PLC in February 29, 2016 (2016 WL 861327 (SD New York)). In sum, the legislative history, documents made by the American competition authorities, and the decisions of the U.S. Supreme Court, suggest that the American antitrust laws were designed to promote consumer welfare.

\section{Protecting American Consumers at the EXPENSES OF FOREIGN SOCIETIES}

Although the main objective of the American antitrust laws is protecting consumer welfare, these laws seem to refer the concept of "consumers" to only American consumers for two reasons. First, the Senator George stated in the Senate debate in 1890 that consumers are "[t]he people of the United States as individuals" ('Senate Debate', 1890, pp. 1767-1768). However, this narrow concept of "consumers" does not mean that the Senate aimed to undermine the interests of foreign consumers but because the law at that time derived from the problems of trusts in the U.S. (Ibid., p. 2457).

The second reason suggesting that the U.S antitrust laws protect only American consumers is exemptions for export cartels. Unlike the first reason, exemptions for export cartel undermine the interests of foreign societies. In 1918, the U.S. Congress enacted the Webb-Pomerene Act which promotes American export trade through the legalization of export associations. It provides that,

[n]othing contained in the Sherman Act shall be construed as declaring to be illegal an association entered into for the sole purpose of engaging in export trade and actually engaged solely in such export trade, or an agreement made or act done in the course of export trade by such association, provided such association, agreement, or act is not in restraint of trade within the United States, and is not in restraint of the export trade of any domestic competitor of such association (Webb-Pomerene Act, 1918, p. §62). 
The Webb-Pomerene Act was enacted for three reasons. First, American exporters especially small and medium-sized enterprises were unable to compete with foreign statesupported cartels (Jones, 1920, p. 754; Immenga, 1995, p. 97). Second, while at that time associations for the promotion of export business were permitted by some developed countries of the world, they were mostly denied by the Sherman Act (Ibid., p. 755). Third, since U.S. exporters faced import cartels in some foreign markets, associations made by American firms would, therefore, make the exporters better off in foreign markets by preventing competition among them (Ibid., p. 757). In general, the purpose of the Webb-Pomerene Act was to promote the productive efficiency of American firms by allowing them to cooperate for the purpose of carrying on export trade.

Although the U.S. government explained that transactions exempt by the Webb-Pomerene Act are not anticompetitive, (World Trade Organization, 2003, para. 37) this Act is supposed to legalize export cartels (Suslow and Levenstein, 2005; Immenga, 1995; Papp, 2012). An association or agreement made for the purpose of export trade by such an association is not prohibited if it is not in restraint of trade within the U.S and is not in restraint of the export trade of any domestic competitor. Therefore, a horizontal cartel may not be prohibited if it is made solely to facilitate export trade. This is inconsistent with the per se approach to cartels of the American antitrust laws.

The legislative history also suggested that the WebbPomerene Act was made to promote exports even when the associations or agreements in question may have adverse competitive effects on foreign markets. Justice Marshall analyzed the opinions of Senator Pomerene and Senator Webb towards this point in United States $v$. Concentrated Phosphate Exp. Ass'n (Concentrated Phosphate). Senator Pomerene said

we have not reached that high plane of business morals which will permit us to extend the same privileges to the peoples of the earth outside of the United States that we extend to those within the United States.... I would be willing that there should be a combination between anybody or anything for the purpose of capturing the trade of the world, if they do not punish the people of the United States in doing it (393 US 199, 1968, pp. 207-208).

Concentrated Phosphate also was the first case in which the U.S. Supreme Court expressed an opinion on the Webb-Pomerene Act.(Ibid., p. 206) Justice Marshall wrote "[i]t is clear what Congress was doing; it thought it could increase American exports by depriving foreigners of the benefits of competition among American firms, without in any significant way injuring American consumers"(Ibid., p. 208) [Emphasis added].

In 1982, the U.S. Congress passed the Export Trading Company Act that aims to "increase United States exports of products and services by encouraging more efficient provision of export trade services to United States producers and suppliers, in particular by...modifying the application of the antitrust laws to certain export trade."(Export Trading Company Act, 1982, sec. 4001(b)) The Act allows the Secretary of Commerce to issue certificates of review and advise and assist any person with respect to applying for certificates of review (Ibid., sec. 4011). A certificate of review shall be issued to any applicant whose export business will:

(1) result in neither a substantial lessening of competition or restraint of trade within the United States nor a substantial restraint of the export trade of any competitor of the applicant,

(2) not unreasonably enhance, stabilize, or depress prices within the United States of the goods, wares, merchandise, or services of the class exported by the applicant,

(3) not constitute unfair methods of competition against competitors engaged in the export of goods, wares, merchandise, or services of the class exported by the applicant, and

(4) not include any act that may reasonably be expected to result in the sale for consumption or resale within the United States of the goods, wares, merchandise, or services exported by the applicant (Ibid., sec. 4013(a)).

The Export Trading Company Act also provides protection from civil or criminal antitrust actions for persons holding a certificate of review (Ibid., sec. 4016(a)). If a certificate holder complies with the standards of section 4013(a), that person will be exempt from the antitrust laws even when the transaction in question may have adverse competitive effects on foreign markets (Ibid., sec. 4013(a)).

Thus, the Webb-Pomerene Act and the Export Trading Company Act aim to limit the range of consumer protected by the American antitrust laws to American consumers. They make efforts to prevent harms that export cartels may cause to American markets but ignore adverse competitive effects to buyers in foreign countries. Such a narrow concept of "consumers" makes the American antitrust policy inconsistent for two reasons.

First, from a national perspective, exemptions for export cartels are inconsistent with the primary objective of the American antitrust laws that protects consumer welfare and the per se approach against cartels. In the context of globalization, the concept of society is no longer confined "to specific states, nations, or regions" but should be viewed as "a world society" (Zumbansen, 2012, p. 309). The concept of "consumers" therefore should not refer to those in any specific national territory but "global consumers."

Second, exemptions for export cartels make American antitrust policy inconsistent at the international level because the U.S is a country vigorously adopting effects doctrine to remedy foreign cartels that have adverse competitive effects to American markets (Phan, 2016, p. 450). A country advocating for the extraterritorial 
application of competition law should not provide exemptions for export cartels that harm foreign societies. The per se approach should be consistently apply to both international cartels affecting American markets and American cartels that affect international markets.

\section{CONCLUSION}

The legislative history, documents made by the American competition authorities, and decisions made by the U.S. Supreme Court suggest that the primary objective of the U.S. antitrust laws is promoting consumer welfare. However, the Webb-Pomerene Act and the Export Trading Company Act narrow the concept of "consumers" to only American consumers by providing exemptions for export cartels. These laws do not remedy agreements that do not have adverse effects on the U.S. territory even if they harm foreign consumers. Exemptions for export cartel, on the one hand, are inconsistent with the objective of American antitrust laws that promote consumer welfare. On the other hand, these measures are inconsistent with the efforts of the American Government to apply the Sherman Act extraterritorially - a measure that aims to protect consumers from international cartels. American antitrust laws, therefore, should abolish exemptions for export cartels.

\section{REFERENCES}

Bork, R. H. (1978) The Antitrust Paradox: A Policy at War with Itself. New York, U.S.: Free Press.

'Brief for the United States as Amicus Curiae Supporting Petitioners in Kathleen R. REITER v. Sonotone Corporation, 442 U.S. 330 (1979)' (1979). 1979 WL 213494 (U.S.).

Brown Shoe Co., Inc. v. United States (1962) U.S.

Connell Const. Co., Inc. v. Plumbers and Steamfitters Local Union No. 100 (1975) U.S.

Cseres, K. J. (2007) 'The Controversies of the Consumer Welfare Standard', The Competition Law Review, 3(2), p. 121.

Export Trading Company Act (1982) 15 U.S.C §§4001-4016.

Federal Trade Commission, The Antitrust Laws. Available at: https://www.ftc.gov/tips-advice/competitionguidance/guide-antitrust-laws/antitrust-laws (Accessed: 4 March 2016).

Gelboim v. Bank of America Corp. (2016) F.3d.

Hovenkamp, H. (2011) Federal Antitrust Policy: The Law of Competition and Its Practice. 4 edition. St. Paul, MN: West.

Hovenkamp, H. (2012) 'Implementing Antitrust's Welfare Goals Symposium: The Goals of Antitrust', Fordham Law Review, 81, pp. 2471-2496.

Immenga, U. (1995) 'Export Cartels and Voluntary Export Restraints between Trade and Competition Policy', Pacific Rim Law E Policy Journal, 4(1), p. 93.

Jones, E. (1920) 'The Webb-Pomerene Act', Journal of Political Economy, 28(9), pp. 754-767.

Kleit, A. N. (1992) 'Beyond the Rhetoric: An Inquiry into the Goal of the Sherman Act', in. Federel Trade Comission Working Paper No. 195, FTC Bureau of Economics.

Kovacic, W. E. and Neilson, W. A. W. (1997) Advisory Report on Approaches to Competition Policy in Vietnam. WB and CIEM.
Kovacic, W. E. and Shapiro, C. (2000) 'Antitrust Policy: A Century of Economic and Legal Thinking', The Journal of Economic Perspectives, 14(1), pp. 43-60.

Lande, R. H. (1982) 'Wealth Transfers as the Original and Primary Concern of Antitrust: The Efficiency Interpretation Challenged', Hasting Law Journal, 34(1).

Lande, R. H. and Averitt, N. W. (1998) 'Consumer Choice: The Practical Reason for Both Antitrust and Consumer Protection Law', Loyola Consumer Law Review, 10(1).

Merced Irrigation District v. Barclays Bank PLC (2016) 2016 WL 861327.

Northern Pac. Ry. Co. v. U.S. (1958) U.S.

Orbach, B. (2013) 'How Antitrust Lost Its Goal', Fordham Law Review, 81, p. 2253.

Papp, F. W. (2012) 'Competition Law and Extraterritoriality', in Ezrachi, A. (ed.) Research Handbook on International Competition Law. Massachusetts, U.S.: Edward Elgar.

Phan, T. (2016) 'The Legality of Extraterritorial Application of Competition Law and the Need to Adopt a Unified Approach', Louisiana Law Review, 77(2), p. 425.

Reiter v. Sonotone Corp. (1979) U.S.

Senate Bills (1889) 'A Bill to Declare Unlawful Trusts and Combinations in Restraint of Trade and Production'. In the Senate of The United States, 51st Congress, 1st Session.

'Senate Debate' (1890). 51st Cong., 1st Sess.

Shapiro, C. (2009) 'Competition Policy In Distressed Industries', in. Competition as Public Policy, U.S: ABA Antitrust Symposium. Available at: http://www.justice.gov/atr/speech/competitionpolicy-distressed-industries (Accessed: 8 February 2016).

Spectrum Sports, Inc. v. McQuillan (1993) S.Ct.

Suslow, V. Y. and Levenstein, M. C. (2005) 'The Changing International Status of Export Cartel Exemptions', American University International Law Review, 20(4), p. 785.

The Senate Committee on the Judiciary (1890) 'S.1 as Reported by the Senate Committee on the Judiciary'.

U. S. v. Concentrated Phosphate Export Ass'n (1968) U.S.

United States v. Topco Assocs., Inc. (1972) U.S.

United States v. Trans-Missouri Freight Ass'n (1897) U.S.

U.S Department of Justice and Federal Trade Commission (2010) 'Horizontal Merger Guidelines'.

Webb-Pomerene Act (1918) 15 U.S.C §§ 61-66.

World Trade Organization (2003) Working Group on the Interaction between Trade and Competition Policy. WT/WGTCP/M/21. WTO.

Wright, J. D. and Ginsburg, D. H. (2012) 'The Goals of Antitrust: Welfare Trumps Choice', Fordham Law Review, 81, pp. 2405-2424.

Zumbansen, P. (2012) 'Defining the Space of Transnational Law: Legal Theory, Global Governance and Legal Pluralism', Transnational Law \& Contemporary Problems, 21(2), p. 305.

$--0-$

\section{ACKNOWLEDGEMENTS}

My sincere thanks to Professor Mark Gillen and Professor Victor V. Ramraj (Law Faculty, University of Victoria, Canada), and Mr. Timothy T. Hughes (the U.S. FTC) for their helpful comments on my draft and to the Centre for Global Studies of the University of Victoria for its great support 